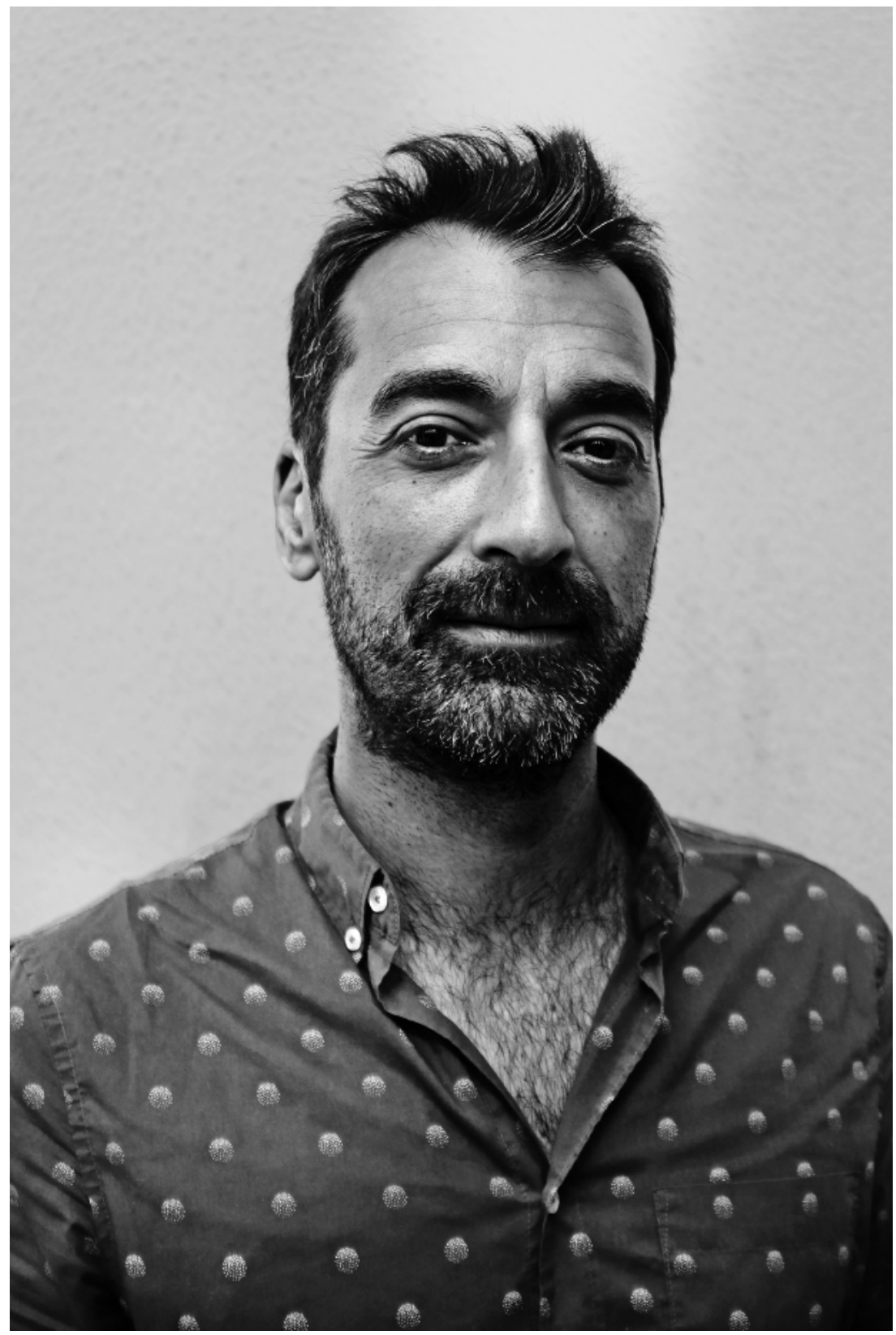

Foto: Hugo Gonçalvez, por Rui Cartaxo Rodrigues. 



\section{"A curiosidade, a forma de olhar o mundo e de o contar" (Uma entrevista com Hugo Gonçalves)}

\section{"The curiosity, the way of looking at the world and telling it" [An interview with Hugo Gonçalves]}

Jorge Vicente Valentim

Universidade Federal de São Carlos (UFSCar), São Carlos, São Paulo / Brasil valentim@ufscar.br https://orcid.org/0000-0002-9275-9801

Resumo: Entrevista realizada com o escritor português Hugo Gonçalves, a respeito de sua obra, notadamente os seus romances ( $O$ maior espectáculo do mundo, 2004 e $O$ coração dos homens, 2006), o seu livro de crônicas (Fado, samba e beijo com língua, 2011) e o seu mais recente título publicado (Filho da mãe, 2019), a ser lançado nesse ano no Brasil, sob a chancela da Companhia das Letras. Alguns temas centram-se no seu projeto de criação literária, além dos assuntos que mais o tocam e interessam, enquanto matéria de suas obras. Observam-se alguns títulos em particular, com um destaque para o seu último livro.

Palavras-chave: curiosidade; escrita ficcional; violência; luto; perda; ficção portuguesa contemporânea; Hugo Gonçalves.

Abstract: Interview with the Portuguese writer Hugo Gonçalves, about his work, notably his novels ( $O$ maior espectáculo do mundo, 2004, e $O$ coração dos homens, 2006), his book of chronicles (Fado, samba e beijo com língua , 2011) and his most recent published title (Filho da mãe, 2019), to be released this year in Brazil, under the seal of Companhia das Letras. Some themes focus on his literary creation project, in addition to the subjects that most touch and interest him, as a matter of his works. There are some titles in particular, with emphasis on his latest book.

Keywords: curiosity; fictional writing; violence; grief; loss; contemporary Portuguese fiction; Hugo Gonçalves. 
Em 03 de fevereiro de 2021, numa quarta-feira à tarde, encontrei o escritor português Hugo Gonçalves ${ }^{1}$ para uma conversa através da sala remota do Zoom. Em tempos de pandemia e de distanciamento social, essa foi a única forma de podermos trocar algumas ideias e conversar sobre a sua obra, os principais temas que o interessam, os incômodos e a sua forma de pensar Portugal e o mundo, além dos projetos futuros, incluindo a publicação, no Brasil, de seu mais recente título: Filho da mãe, sob a chancela da Companhia das Letras.

JVV - Muito boa tarde! Em primeiro lugar, quero agradecer a sua disponibilidade em aceitar conversar pelo Zoom, já que um encontro pessoalmente seria impossível no atual contexto de pandemia.

Hugo Gonçalves - Muito boa tarde, Jorge! Eu é que agradeço a atenção às minhas obras e ao meu trabalho.

JVV - Quando pesquisamos um(a) autor(a), quase automaticamente, vamos para o Google e digitamos o nome para buscar alguma informação ele(a). No teu caso, ao escrever Hugo Gonçalves, temos como resposta alguns dados como, por exemplo, a tua formação em Comunicação Social, pelo ISCSP, o teu ofício como jornalista fundador da revista Focus, premiado com uma reportagem sobre as cheias na Venezuela

${ }^{1}$ Natural de Sintra, Portugal, Hugo Gonçalves é um dos mais talentosos escritores de sua geração. Nascido em 1976, estudou Comunicação Social no Instituto Superior de Ciências Sociais e Políticas da Universidade de Lisboa e estreou-se como jornalista na equipe fundadora da revista Focus. Em 2000, foi distinguido com o "Prémio Revelação do Clube Português de Imprensa", com a reportagem "Esto es el fin del mundo", sobre as cheias na Venezuela, ocorridas em dezembro de 1999. Morou e foi correspondente de várias publicações portuguesas em Nova Iorque, Madrid e Rio de Janeiro, além de assinar crônicas colunas em veículos de imprensa como Jornal de Notícias, Diário Económico, Expresso, revista Visão e o Diário de Notícias. Autor dos romances $O$ maior espectáculo do mundo (2004), O coração dos homens (2006), Enquanto Lisboa arde o Rio de Janeiro pega fogo (2013), o livro de crónicas e micro-ficções Fado, samba e beijo com língua (2011) e $O$ caçador do verão (2015), Hugo Gonçalves lança em 2021, pela chancela da Companhia das Letras, no Brasil, o seu mais recente livro: Filho da mãe (2019), obra com a qual se destacou como finalista do "Prémio Pen Clube" e do "Prémio Fernando Namora" em 2020. 
de 1999, colunista do Diário de Notícias, coautor e guionista das séries País Irmão e Até que a vida nos separe, escritor reconhecido pelos seus pares, finalista de importantes prêmios (Pen Clube e Fernando Namora), enfim, informações que, muitas vezes, se repetem ao longo dos sites de livrarias, por exemplo. Por isso, como sempre gosto de iniciar as entrevistas que faço, começo por perguntar: quem é Hugo Gonçalves?

Hugo Gonçalves - (risos) Pergunta para vários anos de psicoterapia, não é? (risos) E para ser respondida depois de várias sessões! (risos) Em relação ao escritor, há pelo menos uma coisa que sempre me motivou: eu acho que o caminho do jornalismo foi um indicador dessa motivação, que é a curiosidade por aquilo que está para além do meu mundo. Ou seja, a curiosidade pelo outro, a curiosidade pela outra cultura, a curiosidade pela música, pela literatura, por todas as formas de saber, pela ciência. Talvez, outras pessoas, com outra genética cerebral, procurem a música, procurem ser cientistas. Mas aquilo que, de certa maneira, estava ao meu alcance, ou era o instrumento em que eu poderia tocar com mais talento, estava claramente ligado com a língua. Ou seja, essa exploração desse mundo além de mim, que acabou depois, por fim, por ser o meu mundo interior - afinal acho que essas duas coisas são indissociáveis! Quando somos mais jovens entendemos logo isso, primeiro olhamos para fora e depois nos voltamos para dentro, e o Filho da mãe (2019) é um pouco isso, é um pouco esse caminho que o livro trata, é um trajeto de regresso, de introspecção. Eu era fascinado pela língua, pela poesia, por ouvir pessoas que falassem bem, e, desde cedo, percebi que essas duas coisas estavam unidas, não é? A curiosidade, a forma de olhar o mundo e de o contar. Como eu não sou o Rimbaud, e aos 19 anos não era um poeta genial, ele também não durou muito tempo (risos). Aos 20 anos, ele fugiu, foi correndo para Sumatra, teve traficantes atrás dele, perdeu uma perna, pronto (risos). Como eu não tive uma vida tão cheia como o Rimbaud e não me passava sequer pela cabeça tentar ser romancista, aos 19 e 20 anos, eu sabia que queria escrever e sabia que um dia, talvez, eu escreveria um livro, mas o jornalismo era um pouco... uma espécie de recruta. Permite o acesso a muitas realidades e permite o trabalho de oficina, porque a escrita é também um ofício. A escrita não é exclusivamente um dom que nos é lançado pelos deuses da inspiração, pelas musas. Não. Ela exige como outros ofícios, como a música, por exemplo. Mesmo os virtuoses do violino ou do piano, de 
outro instrumento enfim, tem de estudar horas e horas a fio. Eu acho que essa ideia da escrita também como um ofício, e não apenas como exercício diletante da inspiração, sempre me fascinou. E ela exige uma certa ética de trabalho. Portanto, escritores como o Philip Roth, que tem também essa visão da escrita, ou então, em Portugal, o José Cardoso Pires, que era um homem atento às coisas, era uma espécie de artesão da escrita, todos esses escritores sempre me fascinaram. Como tal, o Hugo Gonçalves, pelo menos enquanto escritor, é alguém que vê o ofício da escrita como algo que é preciso praticar uma e outra vez, todos os dias para se conseguir a chegar a um nível de profundidade e de excelência, que, na verdade, nunca se alcança!

JVV - Vindo, portanto, da área de Comunicação Social, como já bem revelaste, até que ponto o teu ofício e o teu olhar como jornalista exercem algum tipo de interferência, seja positiva ou negativa no teu trabalho como ficcionista?

Hugo Gonçalves - Veja bem, quando eu morei nos Estados Unidos, percebi que lá, a palavra escritor (writer) aplica-se a tanto a pessoas que escrevem em jornais, quanto às que escrevem livros. Portanto, existe o ofício de escritor e ele é usado mediante aquilo que lhe é pedido. Truman Capote, por exemplo, produzia seus textos para The New Yorker, uma reconhecida revista. O seu A sangue frio (1966), antes de mais, é uma reportagem, ou seja, é uma reportagem que é uma obra literária. E eu acho que, no mundo anglo-saxônico, não existe tanto essa distinção entre os dois trabalhos (de escritor e o de jornalista). No mundo latino, várias vezes, esbarramos com essa ideia: é um jornalista que vem para a literatura. Isso, para mim, nunca foi uma divisão! $\mathrm{Ou}$ seja, sempre fui alguém para quem a escrita é uma ferramenta. Olhe que há jornalistas que escrevem muito melhor que certos escritores, ou seja, que nunca publicaram um livro, mas, quando abrimos uma matéria ou uma reportagem de cinco páginas, por exemplo, percebemos que esta é muito melhor que uma obra de 200 páginas. Portanto, existe uma sobranceria do mundo literário em relação ao jornalismo que, para mim, não faz sentido. Existem bons e maus escritores, e existem veículos dessa escrita, porque o mundo está cheio de maus livros, não é? Agora, sem dúvida, aliás, eu não sei se, em certa altura, foi o trabalho de jornalismo que contaminou minha escrita de livros, no sentido da 
curiosidade, do mundo visual, às vezes até factual, se isto já existia antes. Ou seja, o meu primeiro livro ( $O$ maior espectáculo do mundo, 2004)... agora não me lembro se foi o primeiro ou o segundo. Enfim. A crítica literária Helena Vasconcelos escreveu no Público uma frase, algo do tipo, "Hugo Gonçalves rompe com a tradição intimista e fechada de uma certa literatura portuguesa" ${ }^{2}$. Eu acho que essa recensão encontra-se disponível na internet, não sei ao certo. Bom, como sabes, a literatura portuguesa, que é variada, tem, especialmente nos prosadores, hoje em dia muito menos, mas durante um bom tempo assim foi, um cânone de uma prosa muito mais poética, muito lírica, hermética. $\mathrm{E} \mathrm{eu,}$ nunca descurando a língua, porque acho que a língua é um instrumento por excelência para se contar alguma coisa, a idéia de contar histórias em que as personagens tenham uma espessura psicológica e em que haja uma narrativa para se destrinchar uma história era algo muito importante para mim. Como tal, o jornalismo é também uma arte de se contar histórias, talvez aí, as duas coisas tenham se fundido, não é? Eu sempre tentei fazer da escrita algo que estivesse colado com a vida. Ou seja, ela tanto pode ser erudita, como coloquial; tanto pode ser introspectiva, como narrativa e cheia de peripécias, porque a vida é assim. Eu nunca olhei para a escrita como algo estanque: "ah, agora, eu só quero ter esse tipo de voz". Por isso, eu gosto muito de escritores que são capazes de, num único parágrafo, citar um autor clássico, a favor da sua história, e, no seguinte, colocar uma personagem a falar com uma gíria típica de um bairro do ABC paulista, por exemplo. Eu gosto muito disso, dessa capacidade de costurar variedades.

JVV - Já no teu primeiro romance ( $O$ maior espectáculo do mundo, 2004), o leitor se depara com personagens em situações-limites, muitas delas em espaços que imprimem uma sensação de degradação e de mal-estar flagrantes: o coronel Lorenzano e o avião luxuoso onde acontecem

2 Trata-se da recensão crítica ao romance de estreia de Hugo Gonçalves, em que a crítica literária Helena Vasconcelos faz a seguinte afirmação sobre $O$ maior espectáculo do mundo: "Para compreender a deslocação brutal do 'eu' interior para a órbita de uma sociedade em tumulto e em estado de promíscua vivência à distância de um botão ao alcance de um dedo, é interessante recrear a (possível) trajectória deste inequívoco talento que vem rasgar uma tradição intimista e incontrolavelmente reprimida na Literatura Portuguesa" (VASCONCELOS, 2004, grifos meus). 
as mais variadas formas de violência, o jovem estudante Michael numa constante sensação de mal estar e de querer vomitar, o doente Pupo, que se encontra internado num hospital dedicado aos soropositivos. Depois, em 2006, em $O$ coração dos homens, o leitor é confrontado com um mundo distópico, marcado pela violência e pelas transformações que uma alteração da ideologia política conduz os seus habitantes. A partir desses enredos, o leitor pode ficar com a impressão de que o Hugo Gonçalves é um escritor apegado ao pessimismo e à distopia ou isso é puramente um recurso de sua retórica ficcional?

Hugo Gonçalves - Não, não. Uma vez uma amiga minha me disse que achava que eu escrevia contra o lixo do mundo. Veja lá, falaste da minha personagem Pupo. Ela foi baseada naqueles que ficavam nos sanatórios em Cuba no início da pandemia da aids e que eram tratados como gente com peste. Eram ostracizados com todos os tipos de discriminação. Desde que eu me lembro de escrever, todos os tipos de injustiça, seja por sua orientação sexual, seja pela sua etnia, seja pela sua nacionalidade, são coisas que sempre me deixaram inquieto. Eu acho que, quando somos jovens - e nesses dois livros, eu tinha menos de 30 anos -, essa revolta com as injustiças e com aquilo que está errado tem um vigor violento. Nós respondemos com um vigor muito maior a essas injustiças. Eu continuo sendo essa pessoa sensível, mas aos quarenta e tal anos, não é por acaso que o meu último livro fala de refugiados judeus e de extremismos de direita. Os temas continuam lá. Talvez, agora, o faça com menos mal do que quando mais jovem, menos reativamente, e, se calhar, de uma forma mais profunda, com uma reflexão mais ampla da natureza humana que não se tem aos 20 e tal anos, não é? Costuma-se dizer que um jovem aos 18 anos é um incendiário, mas aos 40 é um bombeiro (risos). Não sei se será exatamente assim, mas sei que, aos 18 anos, eu era mais incendiário, no sentido de que, quando somos adolescentes, tudo é muito dramático e mais intenso, e as injustiças do mundo se revelam como expressão quase física da dor do outro. Eu acho que a minha visão não era tanto pessimista, mas era mais de uma vontade de mostrar a minha revolta com essas situações injustas e dizer: "Isto é que está mal! Olhem para isto!"

JVV - Se observarmos a materialidade dos títulos que já publicaste, percebe-se pelas contracapas e pelas badanas, uma mudança física nítida 
do Hugo Gonçalves pelas fotografias que lá estão. Ou seja, aquele Hugo Gonçalves de 2004 não é (e jamais poderia ser, por questões óbvias) o mesmo de 2021. O Hugo Gonçalves, mesmo com essa consciência da passagem do tempo, tem algum tipo de sentimento de recusa em relação a $O$ maior espectáculo do mundo? Pergunto porque sabemos de casos de autores que tinham uma relação muito reticente com as primeiras obras, vide os casos de Natália Correia (com Anoiteceu no bairro) e José Saramago (com Terra do pecado). Esse é também o teu caso?

Hugo Gonçalves - Não. Da outra vez que nos falamos, contei-te a história do poeta português que ia sempre a sebos a andar a procura de exemplares do seu primeiro livro, e sempre que os encontrava, enterrava-os todos no seu quintal (risos). Eu não vou tão longe a esse ponto. Eu entendo que os escritores façam isso, não me choca, é muito difícil. Imagina tu chegares a um nível de maestria como o de um Saramago, e, aos 60 anos, olhar para um livro e dizer "Isto foi feito por alguém que não tem o virtuosismo que eu tenho hoje"! Eu não sei o que direi aos 60 anos, mas, a verdade é que o meu perfil de escritor e de pessoa é de alguém que acredita que existe um arco de aprendizagem, enfim, existe um arco na vida. E aceita bem as insuficiências do garoto de 24 anos que queria muito escrever um livro. Eu escrevi com 25, acho eu. Como tal, eu não posso negar esse garoto, mesmo sabendo que eu já fui esse garoto, porque seria como negar parte da minha vida. Eu só sou o escritor que sou hoje porque escrevi O maior espectáculo do mundo (2004). O que eu acho que acontece muitas vezes é que o mundo está cheio de artistas adiados que estão à espera do momento certo para escrever a obra- -prima, que nunca vão escrever! Não há ninguém - claro, obviamente, a não ser que seja um Rimbaud! -, serão poucos, em raríssimas vezes até, os escritores, os artistas (pintores, músicos, etc.), que produzem algo de excelência logo na primeira tentativa. Isso não existe, não é humano. E quando olho o que escrevi, as personagens que mais me interessam trabalhar, as pessoas que mais me interessam conversar, são aquelas em que o arco da sua vida apresenta uma mudança. Ou seja, seria muito triste que eu, ou qualquer outra pessoa, fosse o Hugo Gonçalves com esse cabelinho penteadinho, com a camisa de gola rolë, que foi criado numa escola católica num bairro de classe alta, que era fruto do seu entorno. Por mais rebelde que eu fosse, eu não deixava de ser um resultado do 
meio onde cresci. Aliás, todos nós somos, seja das favelas da zona sul carioca às coberturas de Higienópolis, em São Paulo. No início das nossas vidas somos uma espécie de esponja, somos aquilo que nos dão, não é? E depois, então, iniciamos o nosso percurso de libertação, de emancipação e de construção. E há pessoas que não porque, quando chegam aos 50 anos, são ainda muito parecidas com aquilo que eram aos 18. Como tal, seja em nível pessoal, seja em nível literário, para mim, o fosso que existe entre o meu último livro e o primeiro não é um indicativo de insucesso, mas um sinal de crescimento. Também não vou ser tão pretencioso e dizer que se trata de um sinal de sucesso, mas é, pelo menos, de crescimento e de amadurecimento. Isso, para mim, é um motivo de orgulho.

JVV - Se o fato de querer observar o mundo pode ser entendido enquanto um gesto motivado pela seu trabalho como jornalista, também é certo que a curiosidade sobre os espaços da cidade exerce uma atração muito particular no Hugo Gonçalves, de uma forma geral. Fado, samba e beijo com língua (2011) e Enquanto Lisboa arde o Rio de Janeiro pega fogo (2013) expõem as suas andanças pelo Brasil e pelos EUA. Quais as recordações que mais marcaram o Hugo Gonçalves escritor nessas duas experiências de morar fora de Portugal?

Hugo Gonçalves - Essencialmente, duas coisas. Uma é a aceitação do outro e de que existem outras formas de vida tão válidas, tão cheias, tão profundas e tão diversas, como as que eu vi. Isso em Nova Iorque é muito notório. Conheci pessoas com um passado completamente diferente do meu, com ambições completamente diferentes. Eram pessoas cativantes e que tinham a capacidade de me fazer fascinar e de me deslumbrar. Isso faz-me questionar muitos conceitos e certezas que tinha. Aliás, para mim, a dúvida é muito mais interessante do que a certeza, porque a dúvida leva ao conhecimento e a certeza das coisas conduz à estagnação. Isso aconteceu também no Brasil e, em particular, no Rio de Janeiro, que eu até conheço melhor. A realidade do morro e do asfalto, toda a herança colonial e pós-colonial duma sociedade, especialmente no Rio de Janeiro, onde você consegue perceber as costuras de uma sociedade escravagista, tudo isso foi muito importante para eu relativizar e deixar de ser menos eurocêntrico. E também, nesse caso, egocêntrico. Diante dos mais de 7 bilhões de seres humanos no 
mundo com suas culturas diversas, isso nos faz relativizar, colocar em cheque as nossas certezas e ver a panóplia de existências interessantes que circulam pelo planeta. Por outro lado, a segunda coisa tem a ver com um revés da medalha, como dizemos por cá, que é me fazer aproximar mais das minhas origens. Eu saí e, quando saí, era muito crítico de Portugal e da cultura portuguesa, do mesmo modo como os brasileiros são em relação ao Brasil ou os norte-americanos em relação aos EUA. Todos somos, não é? Faz parte. Mas, depois de viver fora, essa distância, tal como quem tem saudades da família, fez-me apreciar algumas coisas que estavam muito perto de casa e que eu, se calhar, não as tinha valorizado no meu país. Por exemplo, falando de um caso mais concreto, a segurança. Portugal sempre foi um país seguro. Os crimes estão num nível quantitativamente menor em relação a outros lugares, os homicídios são poucos. Como tal, quando você tem alguma coisa que tem desde criança, parece que você não vê isso como um bem essencial. E eu lembro-me que, já havia morado no Brasil, no Rio de Janeiro, e entendia a importância da segurança. Um dia, uma amiga minha com quem havia trabalhado veio cá a Lisboa, e quando nos encontramos na Baixa, ela me pergunta: "ah, é tranquilo aqui falar no celular?". E eu disse: "como assim?". Ao que ela me explicou: "Sim, é tranquilo falar aqui na rua com o celular? Ninguém vai pegar aqui o meu celular?". Eu a acalmei dizendo que aqui ninguém passa correndo a pegar o celular do outro. Ou seja, é normal no Rio, em certas regiões, você pensar isso, faz parte das suas defesas. Ela ficou surpresa quando me perguntou se poderia caminhar para casa às 2 da manhã e eu disse "pode!". Tipo, claro que pode acontecer de haver um assalto, mas é tão raro de isso acontecer aqui no centro de Lisboa. Então, houve algumas coisas, isto é apenas um exemplo de um aspecto prático. Há um ditado, que eu acho que o aproveito em Filho da mãe, que diz "Deixa o teu filho chegar o mais longo que ele conseguir. E, então, quando ele chegar no mais longe que ele conseguir, ajuda-o a voltar a sua casa". E essas viagens e a possibilidade de viver em outros lugares do mundo ajudaram-me a querer voltar a casa, e não é por acaso que - e isto é muito comum nos escritores -, nos meus últimos livros (e talvez nos próximos também), há um regresso. Ou seja, em $O$ caçador do verão (2011), fala-se da linha de Cascais e do Estoril, onde eu cresci; em Filho da mãe, também. É um regresso a um universo, que é a minha origem. Portanto, essa experiência no exterior obrigou-me a voltar ao interior. 
JVV - Há 2 crônicas deliciosas em Fado, samba e beijo com língua (2011) e ambas relacionadas com escritores. A primeira é "Passeio com poeta morto", em que o narrador se reencontra Fernando Pessoa e, depois de um breve passeio pelo Chiado, o teu narrador conclui: "Levei-o aos restaurantes dos Armazéns do Chiado. Disse-lhe: 'Quereres uma pita?' Fernando Pessoa olhava para as adolescentes maquilhadas e de calções tão curtos como uma peça de roupa que encolheu na máquina. Repeti: 'Queres uma pita shoarma?' Ele disse-me que aquele lugar era triste como as casas de pasto onde jantava sozinho. Ponderei perguntei-lhe pela Ofelinha, mas tínhamos fome. No Rossio perguntei: 'Chamo-te um táxi?' Ele: 'Obrigado, mas uma das coisas boas de estar morto é o dinheiro que se poupa em transportes. Isto não anda fácil'. E depois bebemos uma ginginha sem dizer uma palavra" (GONÇALVES, 2011, p. 67). O leitor, aqui - e corrija-me se estiver fazendo uma leitura errada -, fica com uma sensação de que, no fundo, por mais distante que esteja a tradição, no fundo ela sempre está viva e presente, ainda que de forma fantasmagórica. Numa época em que se tem falado tanto sobre esse aspecto, sobretudo nas redes sociais, como é a tua relação com os chamados "clássicos" da literatura? Quem são os principais fantasmas (no sentido positivo) com os quais o Hugo anda a caminhar?

Hugo Gonçalves - Deixe-me só fazer um reparo, porque, para um brasileiro, mesmo para um brasileiro, como tu, que conheça bem Portugal e a cultura portuguesa, há um jogo de palavras aí que, talvez, não tenhas percebido. Só um português saberia a armadilha. "Pita" é uma "pita shoarma", aquela comida israelita, certo? Mas "pita" é o que os portugueses chamam aos "brotinhos", as meninas mais jovens. Então, quando o narrador diz “Queres uma pita?", há um jogo de palavras, porque Fernando Pessoa não sabe se ele está falando da comida ou das jovens que passam pelo Chiado. É um trocadilho de palavras com sentido sexual, uma brincadeira que não tem qualquer tom ofensivo, é importante que se diga. Iniciaticamente, há quatro autores que são super inspiradores e, ao mesmo tempo, super esmagadores. $\mathrm{O}$ primeiro deles, como a crónica que citaste deixa bem claro, é Fernando Pessoa. Os primeiros versos que escrevi, aliás, eram cópias horríveis, obviamente, de alguns versos dele (risos). E, depois, quando comecei a escrever prosa, logo ali aos 18, 19 anos, o José Saramago e o António 
Lobo Antunes. O Lobo Antunes porque tem um estilo que se pega, a partir do momento que se tem a chave para entrar no universo daqueles livros, fica como uma música que não sai da cabeça. Portanto, houve uma série de escritores que caíram na tentação de tentar reproduzir o Lobo Antunes, e, como é de se esperar, a cópia nunca é tão boa quanto o original. E o Saramago porque, além do seu domínio linguístico e de sua voz extremamente peculiar, é um criador de histórias com uma originalidade e com uma ressonância no seu próprio tempo, muito difíceis de escapar. Doutra maneira, por fim, o José Cardoso Pires também porque, além de ser um grande artesão da língua, tem um lado de que eu gosto muito que é um lado mais de rua. É capaz de estar ali com a sua erudição, mas não deixava de conhecer as ruas muito bem, os meandros, os subterrâneos da vida lisboeta, dos marginais e dos boêmios, e da polícia, tal como acontece em Balada da praia dos cães (1982) ou mesmo na Alexandra Alpha (1987). Tudo isso sempre me fascinou. Para mim, esses quatro são geniais, claro que há outros que também poderiam ser citados porque existem influências que vão para além deles. Mas eles são sempre uma sombra para quem quer começar a escrever. E depois, há também alguns poetas que adoro: o David Mourão-Ferreira, que é um poeta de inspiração clássica, um romântico com poemas de amor e poemas eróticos mais fantásticos. Sei inclusive alguns de cor (risos). O Al Berto por quem me apaixonei de forma imediata. Eu tenho a compilação da sua obra desde $O$ medo (1987). Além da poesia dele, que acho fascinante, o percurso dele é absolutamente incrível, porque foi um homem que viveu fora, foi para Barcelona, a sua sexualidade, as suas escolhas, a sua orientação sexual (ele acabou por morrer devido a complicações da aids), num período em que assumir a homossexualidade não é a mesma coisa que agora. Era preciso uma coragem para o fazer. Portanto, tenho um grande fascínio pela poesia do Al Berto. E basicamente essas são as minhas grandes referências portuguesas.

JVV - Bom, falando ainda sobre Saramago, a segunda crônica, e essa sugestivamente autobiográfica, é sobre o teu encontro com José Saramago em Nova Iorque ("O homem duplicado"), quando o Hugo se transforma em personagem principal da crônica. No $1^{\circ}$ encontro em Nova Iorque, o Hugo era garçom no restaurante e teve a oportunidade de servir e conversar com José Saramago. Tentou the dizer que estava 
a escrever, mas não conseguiu. No $2^{\circ}$ encontro, em Madri, o Hugo era cliente e estava a ler uma revista num café, novamente reencontra Saramago, tenta lhe dizer que já era escritor, mas não consegue. E, por fim, conclui: "Desses encontros, há um exemplar de Money com a assinatura de Saramago e a sensação de que o acaso dos eventos em Nova Iorque e Madrid podia ser a premissa de um romance. Não foi, nem será. Ficou por dizer: Senhor Saramago, eu também escrevo, e a si cabe-lhe alguma responsabilidade. Depois de ler um dos seus livros, pensei: 'Quero saber como se faz isto tão bem'. Prometo-lhe que continuarei a tentar"' (GONÇALVES, 2011, p. 136). De um certo modo, a tua resposta anterior já respondeu a pergunta sobre os escritores da geração de José Saramago que mais tiveram uma influência na decisão de Hugo Gonçalves se tornar escritor e na forma de arquitetar os temas e as bases estruturais da sua compreensão narrativa. O Hugo continua a pensar como o Hugo Gonçalves da crônica?

Hugo Gonçalves - Claro, claro. Eu já respondo a tua pergunta, mas todos os escritores, acho, se vão reconhecer nisso, porque não há nada pior que você estar numa festa ou num lançamento de livro, e alguém chegar e dizer: "Ah, sabe, eu também escrevo". A última coisa que você quer fazer é falar sobre escrever. Lembro uma vez, eu estava num bar às 03 da manhã com amigos, e eu queria era dançar e encher a cara, e estava uma a pessoa a insistir: "Não, porque eu também escrevo". Como tal, como eu conto na crônica sobre o Saramago, nas duas vezes em que tive a oportunidade de lhe dizer isso, nunca era no sentido de que eu escrevia, mas era no sentido da gratidão, de poder dizer: "Se eu escrevo, é por causa do Senhor. Muito obrigado!". Ter-se-ia resumido a isso, nunca no sentido de tentar falar com ele, de tentar partilhar os meus livros com ele ou coisa do tipo: "Ah, eu também faço o que o Senhor faz". Nunca, jamais. Seria sempre numa atitude de gratidão. E sim, eu continuo a pensar daquela forma. Ontem, estava a conversar com uma amiga minha e ela me dizia: "Hugo, como é que você consegue levantar-se de manhã e fazer um livro sem um chefe. Porque eu só consigo fazer as minhas coisas ouvindo um chefe". Eu tentava explicar: é claro que adoro que as pessoas leiam os meus livros, sobretudo quando elas me escrevem dizendo que os meus livros as tocaram; que quero ganhar dinheiro com os meus livros, que quero ser reconhecido pelo meu trabalho, sem dúvida alguma. Mas, quando 
eu me sento nessa mesa para escrever, não é nada disso que eu penso. O que me dá entusiasmo e o que me faz andar para frente é o processo em si mesmo. É o processo de me sentar, de criar e de escrever, que, às vezes, é muito angustiante também, não é sempre prazenteiro. Eu ouvi um escritor norte-americano, Jonathan Frenzen, dizer que, se somasse todos os seus livros, o tempo que passou a escrevê-los daria cerca de 5, 6 anos, e que esses eram os melhores 5, 6 anos da vida dele. Claro que eu entendo o que ele quer dizer, ou seja, o melhor tempo da minha vida não é aquele em que estou a escrever, mas o processo de estar a escrever, de melhorar de livro para livro, de trabalhar uma frase, de embalar um parágrafo e conseguir colocar uma ideia, ou um sentimento ou uma imagem, recorrendo aos signos da linguagem, de uma forma não só lúcida, mas também cativante, apelativa para o outro. Enfim, o melhor tempo é aquele em que, através disso tudo, o escritor consegue desenvolver com o leitor a partilha de uma vida humana, seja ela de um sentimento, ou de um reflexo de uma luz numa parede branca numa tarde verão. Pode ser uma sensação ou algo psicologicamente mais profundo. Enfim, é esse processo de criação que me faz querer escrever, e nesse aspecto, falando de José Saramago, espero um dia fazê-lo tão bem. Essa é a sina, a maldição e a benção do escritor, simultaneamente, que é ficar sempre aquém daquilo que nos propomos, por isso, é preciso sempre escrever outro livro, depois outro, e depois outro.

JVV - Vamos voltar à questão da distopia. Em 2006, tu lanças um dos mais violentos romances que tive a oportunidade de ler, O coração dos homens, onde tudo se passa num território inóspito e distópico. Os homens banem as mulheres e formam uma sociedade onde a violência, a intemperança, a intolerância e a incompreensão imperam. $\mathrm{O}$ curioso é que você escreve e publica esse texto, muito antes de acontecer uma difusão mais ampla, mais global, da chamada "masculinidade tóxica". Bem antes, por exemplo, de $O$ código dos homens (The way of men, 2012), de Jack Donovan, um confesso autor de extrema-direita e defensor da manutenção dessas masculinidades. Observem-se os dois títulos em questão, o do teu livro e o do norte-americano. Passados 15 anos, e todas as ocorrências que assistimos, não só em Portugal, na Europa e no Brasil, mas no mundo de uma forma geral, se o Hugo tivesse a oportunidade de escrever um outro romance como aquele, deixaria tal como está? Ou alteraria e em que alteraria? 
Hugo Gonçalves - A premissa que me fez escrever o livro, ou seja, como uma adesão coletiva se torna um delírio - e, muitas vezes, as ideologias são delírios coletivos, seja os religiosos, seja os políticos -, a fé cega num líder messiânico que se apresenta como aquele que vai salvar o país ou a humanidade, muitas vezes, em oposição ao outro, e isto repetiu-se várias vezes na história, era algo que me deixava inquieto. E, na altura quando eu comecei a escrever o livro, já tinham se passado 2 ou 3 anos sobre o 11 de setembro e haviam algumas questões em pauta, como o terrorismo islâmico, ou seja, o que leva aqueles homens entrarem em aviões e a irem contra edifícios? $\mathrm{O}$ fato não só de matarem, mas matarem inocentes que nem sequer eram alvos militares! Isso, obviamente, remete depois à Inquisição medieval, ao nazismo das décadas de 1930 e 1940. Ou seja, o que é que leva e quais eram as condições que fazem alguém a perder o equilíbrio e acreditar em algo que é tão danoso, não é? E acreditar com uma convicção inabalável, a ponto das pessoas ficarem cegas! E a mim, parecia-me que a questão da masculinidade tóxica, que, na época, acho que não existia e eu nunca pensei nele, me incomodava, porque existia, e sempre existiu, a violência doméstica sobre as mulheres, a violência entre garotos. Eu estudei num colégio exclusivo de rapazes e, portanto, as disputas e a violência eram coisas comuns, tipo, os mais fortes se impondo sobre os mais fracos e a dominação física sobre o outro eram coisas que eu conhecia bem. Eu tentei levar isso, então - aliás, como faço sempre nos meus romances -, esticar a corda até o ponto de não se aguentar mais. Se formos ver com atenção, aquilo que acontece no livro, apesar de ser uma distopia, ocorre em várias partes do mundo. Acontece nas favelas do Rio de Janeiro, entre milícias e bandos criminosos, como em certas cidades europeias, nos ataques dos neonazistas sobre grupos de imigrantes. Acontece com os malucos na invasão do Capitólio, nos EUA. Agora, se eu tivesse de escrever um livro com a mesma premissa, eu escrevia a mesma história hoje, porque tenho outra idade, não abusaria tanto da violência gráfica que estaria lá e, quem sabe, daria uma espessura psicológica mais densa a algumas personagens, porque elas, tirando talvez o protagonista, em algum momento, estão para lá de qualquer iniciativa de salvação. Parece que são personagens quase irresgatáveis, não é? Eu não gosto de pensar no ser humano como alguém que não pode ser resgatado de sua condição. Talvez, hoje em 
dia, se escrevesse o livro, teria mais esse cuidado, mas, mais uma vez, isso vem ao encontro daquilo que falamos: o rapaz de 26 anos, que escreveu $O$ coração dos homens e queria mostrar a sua revolta com a violência, sobretudo sobre aqueles que não se podem defender, só sabia se expressar sobre a violência, só sabia dizer o seu asco pela violência, dessa forma. Ou seja, tinha menos sofisticação, menos matizes, menos nuances. Hoje em dia, creio que tenho um pouco mais de sofisticação para tratar esse tema.

JVV - Eu queria ler um trecho para a minha próxima pergunta, do teu último livro, Filho da mãe (2019): "Mas aí reside a diferença entre a adição e a escrita. Na primeira, revelamo-nos ao fugir. $\mathrm{Na}$ segunda, revelamo-nos ao ficar. Se as drogas são a evasão e o esconderijo, a escrita é o peito aberto às balas. É imperativo que eu enfrente, descubra e escreva na proporção exata da devastação que apagou tudo" (GONÇALVES, 2019, p. 93). Esse texto é completamente diferente de todas as obras anteriores. Aliás, isto é algo espetacular e não constitui qualquer tipo de crítica. Mas, como dizia, Filho da mãe constitui uma aventura de escrita muito distinta das demais, não só pela questão da distopia espacial (se o formos comparar com $O$ coração dos homens, por exemplo), mas também pelo caráter autobiográfico. Inclusive, a foto de entrada é de um menino com a mãe, e ambos não aparecem frontal e completamente expostos. Daí a minha leitura de que esse texto, mais do que uma autobiografia, pode ser lido também como uma espécie de autoficção, porque somente com a licença poética da criação ficcional esses pequenos vestígios e essas ruínas do passado poderiam ser reconstruídos, remontados e realocados na narrativa. Se, por um lado, nem a mãe e nem o garoto aparecem com as faces totalmente descobertas, por outro, a forma como você lida com esse passado é intensamente frontal, ou, como bem diz o teu narrador, com o "peito aberto às balas" e disposto a escrever "na proporção exata da devastação que apagou tudo". Como foi a experiência de lidar com esse passado marcado por um acontecimento tão dolorido?

Hugo Gonçalves - Essa passagem que tu leste, de certo modo, sintetiza bem a resposta. Não que tenha sido conscientemente, mas, durante muito tempo, eu tinha passado a fugir dele. E essa fuga se dava muito mais em nível de inconsciente mesmo: as viagens, as mudanças, o hedonismo, 
o experimentalismo, enfim, mas nem tudo eram coisas más. Há uma frase de Ernest Hemingway que diz qualquer coisa, como "Descobre onde dói e escreve sobre isso". Não sei se a tradução será exatamente isso, mas isso diz um pouco sobre o mote usado para escrever o Filho da mãe: o luto se faz ficando e não se faz fugindo. Aliás, eu mesmo digo isso em outro momento do livro. É preciso esperar, porque o tempo do luto é o tempo do pão e do vinho. Não se pode acelerar o processo de fermentação deles, não é? É preciso esperar que o pão cresça e que o vinho envelheça, e assim também o processo do luto e da dor. Mas o processo da escrita e o da edição não são diferentes porque eles exigem tempo! É engraçado porque, hoje, alguém partilhava uma entrevista, acho que era do Milton Hatoum, o escritor brasileiro, que dizia uma coisa, que eu também venho a dizer há anos: o tempo da literatura não está em sintonia com o tempo que vivemos hoje das redes sociais, ou seja, ninguém escreve um livro como se escreve um post no Facebook, por exemplo. E então, a escrita desse livro exigiu-me isso, e se calhar daí também a diferença com $O$ coração dos homens, porque esse é um livro a $200 \mathrm{~km}$ por hora à frente, uma espécie de cavalgada imparável rumo à autodestruição. Eu o definiria assim, e que é, aliás, a vida de muita gente. Já o Filho da mãe, em determinada altura, julgo que logo no início, diz qualquer coisa como: há um momento na vida que nós deixamos de fantasiar com apenas aquilo que está adiante, pelo futuro, ou seja, quem vamos ser, onde vamos crescer, qual vai ser o nosso ofício, quem vai ser o nosso parceiro, porque nos sentimentos compelidos a olhar para trás. De onde nós viemos? Como nós chegamos a ser a pessoa que nós somos agora? Há quem chame isso de meia idade (risos). Mas, foi o que eu senti. Nesse livro, eu tinha que parar e que parar de me esconder na fuga e nas personagens. E a forma como eu abordei e abracei os temas diz muito sobre isso. Fala-se muito em autoficção, mas a autoficção implica que se ficcionalize algo conscientemente. Se há algo que foi ficcionalizado propositadamente foi apenas porque a minha memória não conseguiu recordar de uma forma e, daí, precisei acionar a dos outros a quem eu recorri. E porque, obviamente, não podemos nos esquecer de que a memória é também ficção, não é? Ela é organizada em função de uma narrativa. Um dos exemplos é que a história da ida de minha para Londres tem várias versões. Eu sempre pensei que minha mãe tinha ido de manhã, e a minha avó insistia que ela tinha ido à tarde. Esse é só um pequeno exemplo de que cada pessoa 
daquela família tem uma memória diferente, mas, confesso que não houve um intuito da minha parte de pensar: "ah, vou fazer assim aqui porque vai ficar melhor para a minha personagem”. Não houve, ou seja, esse livro é assumidamente autobiográfico, mas, por outro lado, não quer dizer que as coisas tenham se passado exatamente assim, mas, pelo menos, é a forma como eu recordo. Essa vontade de abraçar a história sem qualquer sentido de censura, de filtro, sem qualquer tipo de superfície almofadada, foi muito libertador do ponto de vista da escrita e do ponto de vista pessoal. Eu acho que não poderia escrever esse livro de outra maneira. A idéia de que escrever esse livro de uma forma lírica, de uma carta em homenagem à minha mãe, em que eu exprimisse os sentimentos em prol dum certo sentimentalismo do leitor ao ler, enfim, tudo isto era algo que causava repugnância. Eu queria que fosse uma reflexão profunda e lúcida (essa palavra me apareceu muitas vezes!) sobre a perda, o luto e os efeitos desses no narrador (que sou eu) e também numa família. Ao longo não só do momento em que a mãe morre, mas, sobretudo, ao longo de 30 e tal anos de vida. Isso, para mim, era muito importante.

JVV - Você acabou de usar uma expressão de que gosto muito, que é essa "narrativa sem filtros", porque isto aparece explicitamente ao longo de o Filho da mãe: "Sinto-me impelido a abandonar todo o pudor, justifico-me com o pressuposto de que, quando se quer escrever um livro, quando se quer ir à raiz do problema, não podemos estar preocupados com aquilo que a família e os nossos amigos irão pensar ou com aquilo que a viagem fará de nós" (GONÇÇALVES, 2019, p. 92). Em muitos momentos, você recupera situações onde o protagonista se expõe de forma aberta e frontal, sobretudo, em cenas com uso de bebidas e drogas. Em virtude dessa visão despojada de qualquer tipo de filtro ou censura, em algum momento, o Hugo não teve medo de possíveis reações negativas a essa forma de expor a intimidade do protagonista e sua forma de ver e estar no mundo?

Hugo Gonçalves - Quando eu me mudei para Nova Iorque, foi imediatamente ao 11 de setembro. E a revista The New Yorker publicou um ensaio do Norman Mailer que se chamava "Carta a um jovem romancista". No contexto do pós-11 de setembro de 2001, num mundo alterado e radicalizado, o que ele aconselhava a um jovem romancista? 
Houve uma frase dele que ficou comigo para sempre, que era algo assim: "se quiseres escrever um livro, se quiseres ir à raiz do problema, não podes estar preocupado com o que vão dizer os teus familiares, os teus amigos, o teu companheiro ou tua companheira". E aquilo teve imensa ressonância em mim - e o Jorge escolheu bem o trecho, porque é disso mesmo que se trata, não é-, mas, naquela época, eu sequer havia escrito o meu primeiro romance, não sequer se entendi a profundidade e a amplitude dessa frase até ter escrito o Filho da mãe, e ela já estava lá. Mas, veja bem, isso não é uma licença para tu seres um filho da puta que se está cagando para as pessoas que estão ao teu lado, ou seja, para tu escreveres expondo e magoando os outros. Não é isso. Não se trata de uma licença de impunidade. Mas, é um alerta para a seguinte questão: tu queres fazer literatura, tu queres tocar ao fundo do problema, ir às entranhas, ao coração dessa coisa fabulosa mas também assustadora que é estar vivo? Então, não podes ter medo disso! Nunca é demais repetir, isso não é uma desculpa para sermos levianos com os outros. Há uma diferença entre as duas coisas.

JVV - Você já tocou nesse assunto, em algumas entrevistas inclusive, a respeito da escrita de Filho da mãe não ter tido qualquer efeito terapêutico, que este não foi o teu objetivo. Como você reage quando os leitores te informam que a leitura de Filho da mãe teve esse efeito na vida deles, exatamente porque não foi essa a tua motivação?

Hugo Gonçalves - Sem sombra de dúvidas, esse foi claramente o livro que originou que mais leitores me enviassem mensagens e chegassem até mim. Muitas delas, não todas, tem a ver com alguma história de perda. De um irmão, de um pai ou de uma mãe. Ainda essa semana, recebi a mensagem de um rapaz que tinha perdido o pai há pouco tempo. Disse-me ele que, após ler o meu livro, tinha de alguma forma sentido uma identificação - e a experiência de identificação é algo muito importante para o ser humano para não nos sentirmos sozinhos - e que o livro havia permitido também ter uma perspectiva em relação a certas experiências íntimas, psicológicas, que ele até chegara a sentir, mas não conseguia ainda expressar de uma forma clara. Ou seja, todos nós temos epifanias ao longo da vida sobre nós mesmos e sobre os outros e, se calhar, para ele o livro foi um verdadeiro estudo sobre o luto, e o luto tem muitos aspectos em comum com todas as pessoas que o vivem. 
Eu nunca pensei nisso ao escrever Filho da mãe, mas, se formos pensar bem, todos os livros mais queridos, aqueles que nós mais admiramos ou que subsistem no tempo, são os que tocam aquilo que é universal: a experiência de estar vivo. Temas como a liberdade, a perda e o amor perpassam a literatura mundial e, como tal, esta ideia de as pessoas se identificarem ou se reverem nessa experiência é muito positiva. No entanto, no que toca ao efeito terapêutico, tu sabes, porque falamos disto com a tua turma de alunos, eu não o escrevi com esse objetivo. Cheguei lá já sabendo muitas coisas, e isto é muito interessante. Como Filho da mãe é um livro sobre a perda e desperta no leitor, por vezes, uma reação emocional ao evento, ele também não deixa de nos fazer pensar porque tem um lado ensaístico, fala de ciência, de filosofia. Portanto, não reduz a perda ao lado sentimental, e tenta abordar o luto através de várias lentes: a da filosofia, a da poesia, a da ciência e a da medicina. Para escrever esse livro com a lucidez e a fluência com que eu queria, eu tinha uma convicção: a ideia de tornar a narrativa numa espécie de novela barroca cheia de filigranas ia completamente contra o propósito do livro. Claro que teve momentos em que eu posso ter me emocionado, sobretudo ao ter descoberto alguma coisa, mas o mais importante é que havia o cuidado do artista que está criando algo. A voz que lá está, a construção dos capítulos, o andar para trás e depois para frente, partes em Nova Iorque, partes na minha infância, recuando até 1985, tudo isso é fruto de um trabalho narrativo-literário que não aconteceu no momento em que me sentei e resolvi num passe de mágica "ah! Agora, o livro vai sair todo de uma vez, numa espécie de fluxo de consciência, e ele vai ser escrito numa única assentada". Não. Existe uma construção gradual e necessária, e que para mim é importante, enquanto escritor.

JVV - Já estamos quase no final e eu gostaria que o Hugo imaginasse a seguinte situação: estamos todos vacinados, as coisas começam a voltar ao normal, Filho da mãe é publicado pela Companhia das Letras. O Hugo chega numa livraria no Brasil e encontra um leitor hipotético de pé, em frente a uma gôndola cheia de livros, ele pega o seu romance e, sem conhecer o autor, dirige-se ao Hugo e pergunta se conhece a obra e/ ou o escritor. O que você diria a esse leitor brasileiro, diante da dúvida de levar ou não o Filho da mãe?

Hugo Gonçalves - Bem (risos). Eu não diria nada. Mas, já vou responder (risos). Por pudor e por educação. Quando as pessoas me dizem que 
compraram meu livro, eu nunca pergunto o que acharam ou se gostaram ou não, porque eu acho que isso é uma intrusão e a leitura é um ato privado, particular. Se elas quiserem me dizer, podem dizer, é claro, mas, por educação e formação, eu jamais o faria. Como disse, acho que seria intrusivo. Por outro lado, entendendo onde tu queres chegar com isso (risos), eu diria ao leitor brasileiro - ainda mais, tendo eu vivido no Brasil e desenvolvido uma relação sentimental com o país, com a cultura e com meus amigos brasileiros -, levando em consideração esse cenário pós-pandemia, que todos esperamos, em que a ideia de perda é ainda tão forte e presente entre nós, com números tão genéricos e avassaladores capazes de nos fazer esquecer o singular em relação a cada uma das perdas (cada pai e cada mãe que perderam um filho, cada irmão que perdeu uma irmã, cada história, cada funeral, cada fotografia que fica sobre a mesa, cada vídeo feito de um aniversário, cada festa de casamento, cada memória), as pessoas podem pensar que um livro sobre a perda é fatalmente um livro triste, e o que eu posso dizer é: quem quer escrever sobre a morte acaba por escrever inevitavelmente sobre a vida, porque não sabemos o que acontece depois da morte. Portanto, mais do que sobre a morte, Filho da mãe é um livro sobre a vida, sobre estarmos vivos e sobre a memória das pessoas que nós mais gostamos. Eu lembro-me de ouvir alguém perguntar: "por que é que morremos?". E alguém responder: "porque, se não morrêssemos, a vida não tinha importância”. E a vida tem muita importância. Como tal, não se deixe enganar porque este livro não é exclusivamente sobre a morte, mas sobre esta coisa esplendorosa e, ao mesmo tempo, assustadora que é estarmos vivos.

JVV - Para encerrar a nossa conversa, como sempre gosto de propor, vamos fazer um jogo de bate e volta. Eu lanço uma palavra e o Hugo responde com a primeira palavra ou expressão que vier à cabeça. Um poeta?

Hugo Gonçalves - Al Berto.

JVV - Uma poetisa?

Hugo Gonçalves - Adília Lopes.

JVV - Um ficcionista? 
Hugo Gonçalves - Philip Roth.

JVV - Uma ficcionista?

Hugo Gonçalves - Rosa Montero

JVV - Uma obra que gostaria de ter escrito?

Hugo Gonçalves - $O$ ano da morte de Ricardo Reis.

JVV - Um escritor que você gostaria de ter levado ao Chiado para tomar um café?

Hugo Gonçalves - Uma emenda, na verdade, eu levaria dois (risos): José Cardoso Pires e Rubem Fonseca.

JVV - Um sonho?

Hugo Gonçalves - Fala-se muito a respeito do Brasil que o gigante acordou. Pois para o Brasil, eu desejava que o gigante dormisse em paz, com sonhos e não com pesadelos.

\section{Referências}

GONÇALVES, H. Fado, samba e beijos com língua. Lisboa: Clube do Autor, 2011.

GONÇALVES, H. Filho da mãe. Lisboa: Companhia das Letras, 2019.

VASCONCELOS, Helena. Hugo Gonçalves e o seu... La Insignia (Cultura), 26 maio 2004. Disponível em: https://www.lainsignia. org/2004/mayo/cul_061.htm. Acesso em: 11 jun. 2021. 